\title{
Diagnostic distribution of 100 strictly unilateral headaches consulting in a specialised clinic
}

\author{
C Ramon", G Mauri, J Vega, M Para, M Rico, G Moris, J Pascual \\ From The European Headache and Migraine Trust International Congress \\ London, UK. 20-23 September 2012
}

\section{Introduction and objectives}

Pain location is an important point in the diagnosis of headaches. Our aim was to analyse the diagnostic distribution of the first 100 patients consulting in our specialised headache clinic due to strictly unilateral headache.

\section{Patients and methods}

Headache diagnoses for all patients sent to our headache clinic in the last year and referring to strictly unilateral headaches were analysed according the current ICH-II classification. We receive patients aged 14 or older.

\section{Results}

The 100 collected patients with strictly unilateral headaches accounted for the $18.9 \%$ of the 528 patients seen in our clinic in the study period. Strictly unilateral headaches were more frequent in males (58\%). Age ranged from 19 to 81 years. Diagnostic distribution was as follows: cluster headache (38 cases) $>$ a variety of secondary headaches $(14$ cases $)>$ migraine $(11$ cases $)>$ cervicogenic headache $(9$ cases $)>$ hemicrania continua $(8$ cases $)>$ nummular headache $(6$ cases $)>$ psychogenic headache ( 5 cases) $>$ paroxysmal hemicrania $(4$ cases $)>$ SUNCT syndrome (3 cases) $>$ stabbing headache $(1$ case $)>$ and probable hypnic headache (1 case).Mean, median and mode of age at onset felt between 47 and 58 years for several diagnoses (cervicogenic headache, nummular headache, psychogenic headaches, hemicrania continua and paroxysmal hemicrania), between 25 and 35 years for cluster headache, below 25 for migraine and, in general, were older than 55 for secondary headaches.

\section{Conclusions}

Strictly unilateral headaches account for almost $20 \%$ of headaches attending a headache clinic. Trigemino-autonomic headaches in general (52\%) and cluster headache in particular (38\%) are the most frequent diagnosis, but, if we include cervicogenic headaches, secondary headaches are diagnosed in one out of five cases. Age can be of important help in their presumptive diagnosis. Supported by the PI11/00889 FISSS grant (ISCIII).

Published: 21 February 2013

doi:10.1186/1129-2377-14-S1-P41

Cite this article as: Ramon et al:: Diagnostic distribution of 100 strictly unilateral headaches consulting in a specialised clinic. The Journal of Headache and Pain 2013 14(Suppl 1):P41.
Submit your manuscript to a SpringerOpen ${ }^{\circ}$ journal and benefit from:

- Convenient online submission

- Rigorous peer review

- Immediate publication on acceptance

- Open access: articles freely available online

- High visibility within the field

- Retaining the copyright to your article 